\title{
Carcass Characteristics of New Zealand White Rabbits at Market Age
}

\author{
R. Rajendran ${ }^{1}$, S. Prakash ${ }^{2 *}$ and S. T. Selvan ${ }^{3}$ \\ ${ }^{1}$ Laboratory Animal Medicine, Tamilnadu Veterinary and Animal Sciences University, \\ Madhavaram Milk Colony, Chennai - 600 051, Tamil Nadu, India \\ ${ }^{2}$ Department of Poultry Management, College of Poultry Production and Management, \\ Tamilnadu Veterinary and Animal Sciences University, Mathigiri, \\ Hosur-635 110, Tamilnadu, India \\ Department of Poultry Science, Madras Veterinary College, Tamilnadu Veterinary and \\ Animal Sciences University, Chennai - 603 203, Tamil Nadu, India \\ *Corresponding author
}

\section{A B S T R A C T}

\begin{tabular}{|l|}
\hline Ke y w o r d s \\
Carcass weight, Cut \\
up parts, Dressing \\
percentage, New \\
Zealand White, \\
Rabbits \\
\hline Article Info \\
\hline Accepted: \\
23 April 2020 \\
Available Online: \\
10 May 2020 \\
\hline \hline
\end{tabular}

The present study was conducted to analyze the carcass characteristics of New Zealand White rabbits reared under tropical conditions of India. For this study, a total of 38 male rabbits of 4 5 months age selected randomly from Post Graduate Research Institute in Animal Sciences, TANUVAS, Tamil Nadu, which were fed with concentrate $(16 \% \mathrm{CP})$ and Desmanthus fodder during the rearing period. The animals were slaughtered by cutting the jugular veins and carotid arteries, various carcass parameters and cut up parts weight were recorded and analyzed as per the standard methods. In the present study, the mean live weight at slaughter and carcass weight observed were $1772.63 \pm 40.65 \mathrm{~g}$ and $911.92 \pm 21.05 \mathrm{~g}$ respectively with a dressing percentage of $51.55 \pm 0.56$ and an edible to inedible ratio of $1.69 \pm 0.04$. The average value of various cut up parts such as fore limb weight, thorax weight, loin weight, abdominal flap weight, rump and hind limb weight and shank weight were $141.91 \pm 4.37 \mathrm{~g}, 177.44 \pm 4.96 \mathrm{~g}, 168.74 \pm 4.98 \mathrm{~g}$, $67.31 \pm 2.05 \mathrm{~g}, 292.30 \pm 6.95 \mathrm{~g}$ and $51.13 \pm 1.29 \mathrm{~g}$ respectively which shows high correlation with live weight especially the prime cut up parts such as loin (0.805), rump and hind limb (0.908) with a significance level of 0.01. From the study, it is evident that among the various foragers like sheep, goat, cattle and rabbit, the dressing percentage of the rabbits seemed to be high with better meat to bone ratio.

\section{Introduction}

In the last decade, meat consumption of the world is increasing especially in the developing countries of Asia. In India, more than $71 \%$ of people over the age of 15 are non-vegetarians (sample registration system (SRS) baseline survey, 2014). The annual meat production of India is 7.4 MT with a growth rate of $5.21 \%$ for the year 2016-17 (BAHS, 2017). Even with steady growth of meat production, the average per capita availability of meat is around $6 \mathrm{~kg} /$ year against the Indian Council of Medical Research recommendation of $11 \mathrm{~kg} /$ year. Dependence on food animals becomes higher 
to satisfy the protein requirement of growing human population. The change in consumption pattern and admirable nutritional qualities paves a great demand for rabbit meat production in the recent years in India.

Rapid growth and technological innovations lead to the structural changes in the livestock sector, of which rabbitry is gaining popularity for meat production because of its least dependence on the concentrate diet. Rabbit meat has high nutritional qualities with outstanding dietetic properties.

The protein content of rabbit meat is around $21 \%$ and total mineral content is $1.5 \%$. The sodium content of rabbit meat is relatively low (49 mg/100 g), whereas the phosphorus level is high $(277 \mathrm{mg} / 100 \mathrm{~g})$ and the cholesterol content is also in the beneficial range of $59 \mathrm{mg} / 100 \mathrm{~g}$ with a better omega 6/omega 3 ratio of 5.9 , which makes the rabbit meat attractive for health purposes (Combes, 2004).

World rabbit population is around 316.69 million and meat production is approximately 1.43 million MT (FAOSTAT, 2016). The contribution of India is very meager in rabbit meat production. Researches about rabbits on meat production aspect under Indian climatic conditions are very scanty. The knowledge about dressing percentage, carcass yield and various cut up parts is essential to assess the meat production of rabbits.

Carcass presented in cut up parts provides a variety of options to purchasers for meat handling, packing and conformity assessment, which conform to good commercial practice for meat and meat products intended to be sold in international trade (UNECE Standard for Rabbit Meat- Carcasses and Cuts - 2013). Information on carcass characteristics is therefore helpful for the effective utilization of rabbit meat (Fernandez and Fraga, 1996).

\section{Materials and Methods}

The study was carried out at Post Graduate Research Institute in Animal Sciences, Kattupakkam which is located at $12^{\circ} 336^{\prime} \mathrm{N}$ latitude and $80^{\circ} 04^{\prime} \mathrm{E}$ longitude near Chennai, Tamil Nadu. The station is situated at $45 \mathrm{~m}$ above mean sea level and receives an average rainfall of around $1136 \mathrm{~mm}$. The average temperature is $28.4^{\circ} \mathrm{C}$ ranging from $38^{\circ} \mathrm{C}$ to $19.4^{\circ} \mathrm{C}$.

After the weaning period of 42 days of age, the rabbits were reared as a pair in galvanized battery cages of $2 \times 1.5 \mathrm{ft}$ size under standard farm conditions. The animals were fed with concentrate of around $40 \mathrm{~g} / \mathrm{kg}$ live body weight in the forenoon and Desmanthus fodder of around $200 \mathrm{~g}$ /animal in the afternoon hours during the rearing period. The concentrate $(16 \% \mathrm{CP})$ was usually presented as wet mash to the animals.

A total of 38 male New Zealand White rabbits aged 4 to 5 months were selected randomly and slaughtered after an overnight feed withdrawal. Slaughtering is conducted by cutting the jugular veins and carotid arteries (Deltoro and Lopez, 1985). Parameters like live weight, weight after blood loss to estimate the blood loss, head weight, dressed head weight, carcass weight, various organ weights, pelt weight and cut up parts weight viz. fore limb, thorax, loin, abdominal flap, shank and rump with hind limb were recorded and analyzed as per the standard methods (Snedecor and Cochran, 1967). Degree of associations was considered between variables by Pearson Correlation Coefficient using IBM SPSS statistics data editor.

\section{Results and Discussion}

The data pertaining to the live weight, blood loss, carcass weight, edible and inedible visceral weight are expressed in mean values 
and percentage in Table 1. The mean live weight at slaughter, blood loss and carcass weight were $1772.63 \pm 40.65 \mathrm{~g}, 57.47 \pm 2.99$ g, $911.92 \pm 21.05 \mathrm{~g}$. The dressing percentage of New Zealand white rabbits obtained in this study was $51.44 \pm 0.56$ which was higher compared to other studies (Yalçın et al., 2006; Murshed et al., 2014; Ghosh and Mandal, 2007 and Bianospino et al., 2004.)

The overall dressed carcass weight with giblet and dressed head was $1081.2 \pm 23.60 \mathrm{~g}$ with a percentage of $60.99 \pm 0.63$ which was higher compared to Yalcin et al., (2006) who studied the meat characteristics of New Zealand White rabbits at Turkey. The overall mean organ weights were heart $6.53 \pm 0.44 \mathrm{~g}$, liver $51.05 \pm 1.77 \mathrm{~g}$, kidney $11.34 \pm 0.46 \mathrm{~g}$, abdominal fat $23.74 \pm 2.43 \mathrm{~g}$ and lungs with trachea $11.97 \pm 0.70 \mathrm{~g}$ which was $0.37 \pm 0.03$ $\%, 2.88 \pm 0.08 \%, 0.64 \pm 0.03 \%, 1.34 \pm 0.13$ $\%$ and $0.68 \pm 0.04 \%$ of live body weight respectively. The values were in resemblance with Yalcin et al., (2006) and slightly higher compared to indigenous rabbits of Bangladesh (Murshed et al., 2014)

Table.1 Carcass characteristics of rabbits (Mean \pm S.E. and percentage in proportion to the live weight \pm S.E.)

\begin{tabular}{|c|c|c|}
\hline Parameters & Mean value (g) & $\begin{array}{c}\text { Mean value } \\
\text { (Percentage of live } \\
\text { weight) }\end{array}$ \\
\hline Live weight & $1772.63 \pm 40.65$ & \\
\hline Head weight & $168.84 \pm 4.27$ & $9.52 \pm 0.21$ \\
\hline Dressed head weight & $100.32 \pm 2.48$ & $5.66 \pm 0.10$ \\
\hline Carcass weight & $911.92 \pm 21.05$ & $51.44 \pm 0.56$ \\
\hline Carcass weight with giblet & $980.84 \pm 21.66$ & $55.48 \pm 0.48$ \\
\hline Carcass weight with head & $1012.24 \pm 23.04$ & $57.10 \pm 0.06$ \\
\hline $\begin{array}{l}\text { Carcass weight with giblet and dressed } \\
\text { head }\end{array}$ & $1081.2 \pm 23.60$ & $60.99 \pm 0.63$ \\
\hline \multicolumn{3}{|c|}{ Edible parts weight } \\
\hline Heart weight & $6.53 \pm 0.44$ & $0.37 \pm 0.03$ \\
\hline Liver weight & $51.05 \pm 1.77$ & $2.88 \pm 0.08$ \\
\hline Kidney weight & $11.34 \pm 0.46$ & $0.64 \pm 0.03$ \\
\hline Abdominal fat weight & $23.74 \pm 2.43$ & $1.34 \pm 0.13$ \\
\hline \multicolumn{3}{|c|}{ Inedible parts weight } \\
\hline Blood loss & $57.47 \pm 2.99$ & $3.24 \pm 0.14$ \\
\hline Pelt weight (with feet) & $290.11 \pm 12.7$ & $16.37 \pm 0.43$ \\
\hline Lungs weight & $11.97 \pm 0.70$ & $0.68 \pm 0.04$ \\
\hline Intestine weight & $304.05 \pm 11.04$ & $17.15 \pm 0.58$ \\
\hline Overall edibles weight & $1104.94 \pm 24.97$ & $62.33 \pm 0.68$ \\
\hline Overall inedibles weight & $663.61 \pm 18.84$ & $37.44 \pm 0.56$ \\
\hline Edibles : inedibles ratio & $1.66 \pm 0.04$ & \\
\hline
\end{tabular}


Table. 2 Cut Up parts of rabbit carcass (Mean \pm S.E. and percentage in proportion to the dressed carcass weight \pm S.E.)

\begin{tabular}{|l|c|c|}
\hline \multicolumn{1}{|c|}{ Parameters } & Mean value (g) & $\begin{array}{c}\text { Mean value } \\
\text { (Percentage of the dressed } \\
\text { carcass weight) }\end{array}$ \\
\hline Fore limb weight & $141.91 \pm 4.37$ & $15.78 \pm 0.26$ \\
\hline Thorax weight & $177.44 \pm 4.96$ & $19.74 \pm 0.30$ \\
\hline Loin weight & $168.74 \pm 4.98$ & $18.73 \pm 0.24$ \\
\hline Abdominal flap weight & $67.31 \pm 2.05$ & $7.51 \pm 0.16$ \\
\hline Rump + hind limb weight & $292.30 \pm 6.95$ & $32.54 \pm 0.21$ \\
\hline Shank weight & $51.13 \pm 1.29$ & $5.71 \pm 0.09$ \\
\hline
\end{tabular}

Table.3 Correlation coefficients among various carcass traits

\begin{tabular}{|c|c|c|c|c|c|c|c|c|}
\hline & LW & DW & FLW & TW & LOW & AFW & RHLW & SW \\
\hline LW & 1 & $.897^{* *}$ & $.773^{* *}$ & $.662^{* *}$ & $.805^{* *}$ & $.628^{* *}$ & $.908^{* *}$ & $.735^{* *}$ \\
\hline DW & $.897^{* *}$ & 1 & $.818^{* *}$ & $.835^{* *}$ & $.898^{* *}$ & $.679^{* *}$ & $.958^{* *}$ & $.777^{* *}$ \\
\hline FLW & $.773^{* *}$ & $.818^{* *}$ & 1 & $.463^{* *}$ & $.807^{* *}$ & $.411^{* *}$ & $.768^{* *}$ & $.552^{* *}$ \\
\hline TW & $.662^{* *}$ & $.835^{* *}$ & $.463^{* *}$ & 1 & $.625^{* *}$ & $.640^{* *}$ & $.771^{* *}$ & $.672^{* *}$ \\
\hline LOW & $.805^{* *}$ & $.898^{* *}$ & $.807^{* *}$ & $.625^{* *}$ & 1 & $.565^{* *}$ & $.820^{* *}$ & $.582^{* *}$ \\
\hline AFW & $.628^{* *}$ & $.679^{* *}$ & $.411^{* *}$ & $.640^{* *}$ & $.565^{* *}$ & 1 & $.574^{* *}$ & $.558^{* *}$ \\
\hline RHLW & $.908^{* *}$ & $.958^{* *}$ & $.768^{* *}$ & $.771^{* *}$ & $.820^{* *}$ & $.574^{* *}$ & 1 & $.756^{* *}$ \\
\hline SW & $.735^{* *}$ & $.777^{* *}$ & $.552^{* *}$ & $.672^{* *}$ & $.582^{* *}$ & $.558^{* *}$ & $.756^{* *}$ & 1 \\
\hline
\end{tabular}

**. Correlation is significant at the 0.01 level (2-tailed)

LW - Live weight, DW - Dressed weight, FLW - Fore limb weight, TW - Thorax weight, LOW -Loin weight, AFW - Abdominal flap weight, RHLW - Rump and Hind limb weight and SW - Shank weight

The mean value of edibles (dressed carcass with head, giblet and fat) and inedibles were $1104.94 \pm 24.97 \mathrm{~g}$ and $663.61 \pm 18.84 \mathrm{~g}$ which contributes $62.33 \pm 0.68 \%$ and $37.44 \pm$ $0.56 \%$ of live body weight respectively with an edible and inedible ratio of $1.66 \pm 0.04$. Whereas in soviet chinchilla males, Ghosh and Mandal (2007) observed lower values of inedibles weight and better ratio of edibles: inedibles. The average value of various cut up parts such as fore limb weight, thorax weight, loin weight, abdominal flap weight, rump and hind limb weight and shank weight were $141.91 \pm 4.37 \mathrm{~g}, 177.44 \pm 4.96 \mathrm{~g}, 168.74 \pm$ $4.98 \mathrm{~g}, 67.31 \pm 2.05 \mathrm{~g}, 292.30 \pm 6.95 \mathrm{~g}$ and $51.13 \pm 1.29 \mathrm{~g}$ respectively. The percentage of various cut up parts in relation to the dressed carcass weight is expressed in Table 2.
The correlations among various carcass traits are given in Table 3 . In the present study, significantly high association observed between the live weight and various carcass traits. The correlation observed between the live weight and dressed weight in this study was similar to Murshed et al., (2014). Of the various cut up parts, loin, rump and hind limb were considered as the prime cut up parts because of its high meat to bone yield.

In the present study, the prime portions of cut up parts such as loin, rump and hind limb showed a high correlation with live weight and dressed weight which was in accordance with the previous studies of Metzger et al., (2011) and Michalik et al., (2006) but lower compared to Nwagu et al., (2009) and higher 
compared to Murshed et al., (2014). In the dressed carcass yield about $50 \%$ is contributed by the loin, rump and hind limp. These are the prime portions of the carcass with high meat yield. Significant correlation of the portions with live weight suggests that the live weight of rabbit is highly correlated with meat yield and high meat to bone ratio.

The dressing percentage of various animals like beef cattle, sheep / goat, swine, turkey and chicken were 57-64, 49-52, 68-72, 77-81 and 70-72 respectively (Aberle et al., 2001). In general among the foragers reared under tropical conditions, rabbit has a better feed conversion ratio of around 3.3 - 5.0 (Gupta et $a l ., 2000)$ and the dressing percentage of the rabbits also seemed to be high with better edible to inedible ratio which is very evident in this study. In future, rabbitry will definitely serve the nutritional requirements of the world with a minimal input.

\section{Acknowledgement}

The authors are thankful to the Professor and Head, Post Graduate Research Institute in Animal Sciences, Tamilnadu Veterinary and Animal Science University, Chennai for providing necessary assistance to carry out the work.

\section{References}

(BAHS, 2017) http://www.censusindia. gov.in/vital_statistics/baseline\%20table s07062016.pdf

Aberle, E. D., Forrest, J. C., Gerrard, D.E. and Mills, E. W. (2001). Principles of Meat Science, Fourth Ed, 2001, Kendall/Hunt Publishing.

Bianospino, E., Wechsler, F. S., Moura A.S.A.M.T. and Fernandes, S. (2004). Growth traits and dressing percentage of straightbred and crossbred rabbits. Proceedings - 8th World Rabbit Congress - September 7-10, 2004 -
Puebla, Mexico.

Combes, Sylvie. (2004). Nutritional value of rabbit meat: A review. Productions Animales, 17, 373-383.

Deltoro, J. and Lopez, A. M. (1985). Allometric changes during growth in rabbits. Journal of Agricultural Science, Cambridge, 105, 339-346.

FAOSTAT 2016. Web: www.faostat.org

Fernandez, C. and Fraga, M. J. (1996). The effect of dietary fat inclusion on growth, carcass characteristics, and chemical composition of rabbits. Jouranl of Animal Science, 74, 2088-2094.

Ghosh, N. and Mandal, L. (2008). Carcass and meat quality traits of rabbits (Oryctolagus cuniculus) under warmhumid condition of West Bengal, India. Livestock Research for Rural Development, 20(9). September, 2008.

Gupta, B. R., Rao, V. P., Reddy, C. E., Sathyanarayana, A. and Reddy, P. P. (2000). Feed inatke and feed conversion ratio in purebred and crossbred broiler rabbits. Indian Journal of Animal Research, 34, $64-67$.

Metzger, S., Odermatt, M., Szabo, A., Radnai, I., Biro-Nemeth, E., Nagy, I. and Szendro, Z. (2011). Effect of age and body weight on carcass traits and meat composition of rabbits. Archives of Animal Breeding, 54 (4), 406-418.

Michalik, D., Lewczuk, A., WilkiewiczWawro, E. and Brzozowski, W. (2006). Prediction of the meat content of the carcass and valuable carcass parts in French lop rabbits using some traits measured in vivo and post mortem. Czech Journal of Animal Science, 51(9): 406-415

Murshed, H. M., Shishir, M. S. R., Rahman, S. M. E. and Oh, D. (2014). Comparison of carcass and meat characteristics between male and female indigenous rabbit of Bangladesh. Bangladesh Journal of Animal Science. 
43 (2): 154- 158.

Nwagu, B. I., Kabir, M. and Suleiman, B. H. (2009). Carcass Characteristics of Different Breeds of Rabbits Raised in Zaria. Savannah Journal of Agriculture, 4, 14-19.

S. Yalçın, S., Onbaşılar, E. E. and Onbaşılar, I. (2006). Effect of Sex on Carcass and Meat Characteristics of New Zealand
White Rabbits Aged 11 Weeks. AsianAustralasian Journal of Animal Sciences, 19 (8), 1212 - 1216.

Snedecor, G. W. and Cochran, W. B. (1994). Statistical Methods. $8^{\text {th }}$ Edn. The Iowa State University Press, Ames, IOWA, USA.

UNECE Standard for Rabbit Meat- Carcases and Cuts - 2013, 4-5.

\section{How to cite this article:}

Rajendran, R., S. Prakash and Selvan, S. T. 2020. Carcass Characteristics of New Zealand White Rabbits at Market Age. Int.J.Curr.Microbiol.App.Sci. 9(05): 2720-2725. doi: https://doi.org/10.20546/ijcmas.2020.905.311 